Informatika i sistemy upravleniya. - 2018. - No. 2(56). - P. 50-61.

Sapozhnikov V.V. (port.at.pgups1@gmail.com), Sapozhnikov VI.V., Efanov D.V., Abdullaev R.B. Emperor Alexander I St. Petersburg state transport university

\title{
ABOUT PROPERTIES OF POLYNOMIAL CODESIN CONCURRENT ERROR DETECTION SYSTEMS
}

The peculiarities of error detection by polynomial codes in data vectors are analyzed in comparison with known modular codes with summation of single data bits. The main features of error detection by polynomial codes are established, which are suitable for the construction of systems with fault detection. It is determined under what conditions it is possible to build completely self-checking structures of concurrent error detection systems based on polynomial codes.

Keywords: concurrent error detection system; duplication; polynomial code; code with summation; modular code with summation; error detection.

DOI: $10.22250 /$ isu.2018.56.50-61

For citation:

Sapozhnikov V.V., Sapozhnikov VI.V., Efanov D.V., Abdullaev R.B. ABOUT PROPERTIES OF POLYNOMIAL CODESIN CONCURRENT ERROR DETECTION SYSTEMS // Informatika i sistemy upravleniya. - 2018. - No. 2(56). - P. 50-61. 